\title{
Interagency Privity and Claim Preclusion
}

\author{
Joel deJesus $\dagger$
}

Federal administrative agencies play an important role in national policy, ${ }^{1}$ directing most of the day-to-day activities of the federal government. The agencies pursue their separate tasks with a good deal of autonomy, and yet the lines dividing their spheres of activity are often unclear. When more than one agency pursues similar goals through adjudication, the result may be duplicative litigation.

The doctrine of preclusion is the procedural device generally invoked to prevent such duplication. Preclusion can take two forms: issue preclusion, which prevents a party from relitigating issues it has already fully litigated, and claim preclusion, which prevents a party from relitigating a claim when it participated in a prior adjudication of these claims or when it was in privity with a party to that litigation. It is this latter form of preclusion that presents a special problem for government agencies.

In a bureaucracy as vast as the federal government, strict application of claim preclusion could prevent agencies from pursuing important policy goals. For example, the Occupational Safety and Health Administration ("OSHA") and the Environmental Protection Agency ("EPA") both may regulate the discharge of toxic chemicals from a particular factory; both may need to go to court to enforce their regulations. But if for some reason OSHA completes its litigation against the factory before the EPA, subsequent litigation by the EPA might be precluded. In cases where agencies have such overlapping responsibilities and where one agency's litigation could preclude legal action by the other, courts have been unable to develop a workable test to balance the agency's interest in litigating its claim against the interest of the judicial system and parties in preventing duplicative suits.

† A.B. 1987, Cornell University; J.D. Candidate 1990, The University of Chicago.

2 This role is not without controversy. See generally Peter L. Strauss, The Place of Agencies in Government: Separation of Powers and the Fourth Branch, 84 Colum L Rev 573 (1984). 
The primary impediment to developing a workable claim preclusion test is the troublesome concept of interagency privity. ${ }^{2}$ Two approaches predominate in the federal courts. ${ }^{3}$ The traditional approach, which finds privity among all officers of the same government, precludes an agency from relitigating a claim brought by any other agency. Some courts have found this approach too preclusive and have moved toward an ad hoc approach based loosely on an agency's interests in a given case. Neither approach, however, considers the importance of an agency's substantive mission or the unique policy considerations that arise in government litigation. A more balanced approach would weigh the complex public and private interests underlying administrative activity against the policies of finality and judicial economy at the heart of the claim preclusion doctrine.

This Comment considers such factors and proposes an alternative standard of interagency privity for claim preclusion: courts should find privity between government agencies when the governing statutes and regulations describing their overlapping responsibilities and interests anticipate a single factual situation. Only then can the courts be faithful to the traditional policies underlying claim preclusion while recognizing the unique relationships among administrative agencies and within the executive branch.

Section I outlines the policies underlying claim preclusion, the concept of privity, and the present federal administrative structure. ${ }^{*}$ Section II analyzes the existing judicial approaches to interagency privity as well as two proposed solutions that the courts have not adopted-the "common superior" and "extended primary jurisdiction" approaches. Drawing on the lessons of these unadopted alternative approaches, section III proposes a new standard for determining interagency privity, one based on the relationships among agencies as manifested in their enabling statutes. Section III also demonstrates how the proposed standard would resolve typical administrative privity questions.

\footnotetext{
2 The courts have settled on a standard of privity for administrative issue preclusion, but they have not developed one for administrative claim preclusion. See text at notes 46 57.

3 See text at notes $40-57$.

- The problem of determining when state agencies are in privity with federal or other state agencies may be as great as the problem of determining privity among federal agencies. Since questions of privity among state agencies are complicated by issues of sovereignty, federalism, and preemption, however, this Comment addresses only federal interagency privity and the problem of coordinating federal agency litigation.
} 


\section{Policy Overview}

A range of possible approaches exists to administrative claim preclusion. The approaches at the extremes highlight the competing interests involved in interagency privity. ${ }^{\circ}$

A court could respect the autonomy within the administrative structure and never find interagency privity. ${ }^{\circ}$ But precluding a claim only when the same agency relitigates would open the way to repetitious litigation, frustrating the values of finality and judicial economy that the claim preclusion doctrine represents. At the other extreme, a court could treat the agencies as one monolithic "government," so that one agency's action would bind all others."

${ }^{5}$ Although this Comment uses a paradigm in which agencies act solely as parties, there are cases in which they are both adjudicators and parties. In the past, many courts hesitated to apply the doctrine of claim preclusion to administrative proceedings. In 1906, the Supreme Court refused to apply res judicata to administrative decisions, reasoning that they were "executive" rather than "judicial" decisions, made in "a summary way, in order to reach [a] 'prompt determination. . . .'" Pearson v Williams, 202 US 281, 285 (1906). But sixty years later, in United States v Utah Construction and Mining Co., 384' US 394, 421 (1966), the Court repudiated that position. The Court accepted the application of res judicata to agencies "[w]hen [the] agency is acting in a judicial capacity and resolves disputed issues of fact properly before it which the parties have had an adequate opportunity to litigate." Id at 422 (citing Sunshine Coal v Adkins, 310 US 381 (1940)); see also Restatement (Second) of Judgments $\S 83$, comment b (American Law Institute, 1982). The Court held, however, that in cases where an administrative agency acts merely as a fact-finding body or uses less rigorous evidentiary standards than those required by courts, preclusion should apply only if the agency employed certain procedural safeguards. Utah Construction, 384 US at 422.

The Supreme Court has since reaffirmed its approval of administrative claim preclusion. Kremer v Chemical Construction Corp., 456 US 461, 484-85 n 26 (1982). Lower courts now regularly recognize the preclusive force of administrative decisions when agencies act in a judicial capacity, noting that the interest in preventing the harms of repetitious litigation that underlies traditional claim preclusion also exists in the administrative context. Facchiano v United States Department of Labor, 859 F2d 1163, 1167 (3d Cir 1988) ("an administrative tribunal cannot refuse to observe these preclusion principles when they do apply") (citing Restatement (Second) of Judgments \& 83(1) and Kenneth C. Davis, 4 Administrative Law Treatise \$ 2:19 at 78-80 (K.C. Davis, 2d ed 1983)); City of Pompano Beach v FAA, 774 F2d 1529, 1538-39 n 10 (11th Cir 1985) (emphasizing importance of "full opportunity to litigate"); and Atlantic Richfield v Federal Energy Administration, 556 F2d 542, 549-50 (Temp Emerg Ct App 1977) (noting necessity of "fair adversary hearings . . supported by substantial evidence"). See also Graybill v United States Postal Service, 782 F2d 1567, 1571 (Fed Cir 1986), and University of Tennessee v Elliott, 478 US 788, 798 (1986).

Not only have courts recognized the preclusive effect of certain administrative adjudications, they also have required agency adjudicators to determine for themselves whether cases before them are precluded by prior judicial or administrative decisions. Facchiano, 859 F2d 1163. The approach suggested by this Comment intends to create a single test for interagency privity regardless of whether the potentially preclusive case was adjudicated in a court or administrative forum or whether the determination of privity is to be made at the agency level or on review by a court.

- For a discussion of agency autonomy, see text at notes 25-32.

" Courts traditionally favor this latter approach. See the discussion of the Sunshine 
This, however, would preclude an agency from acting regardless of whether it had a reasonable opportunity to preserve its claims in the first suit; agencies would be hindered in achieving the substantive goals for which they were established. Any rule of privity, therefore, must serve as the fulcrum upon which an agency's interest in pursuing its substantive mission can be balanced against the policies of finality and judicial economy underlying claim preclusion.

\section{A. Claim Preclusion and Privity Policy}

The doctrine of claim preclusion provides that a final judgment on the merits "bars further claims by parties or their privies based on the same cause of action." The cause of action is said to be "merged" into a judgment for the plaintiff, and a judgment for the defendant is said to "bar" subsequent suits by the original plaintiff and its privies on the same transaction. ${ }^{9}$

\section{Claim preclusion policy.}

The courts recognize several policies underlying claim preclusion and the related doctrine of issue preclusion. Foremost among these are the goals of finality, consistency, judicial economy, and fairness. ${ }^{10}$ Absent claim preclusion, plaintiffs could bring multiple suits based on multiple claims for relief arising from a single transaction. Claim preclusion prevents plaintiffs from bringing the same evidence into the same forum under different legal theories, ${ }^{11}$ thereby limiting inconsistency in court decisions, barring vexatious suits, ${ }^{12}$ and achieving judicial economy by preventing piecemeal litigation. ${ }^{13}$ In contrast to issue preclusion, which only prohibits re-

rule in the text at notes $40-48$.

${ }^{8}$ Montana $v$ United States, 440 US 147, 153 (1979) (citing Cromwell $v$ County of Sac, 94 US 351, 352 (1877)). See also Parklane Hosiery Co. v Shore, 439 US 322, 326 n 5 (1979).

- Cooper v Federal Reserve Bank of Richmond, 467 US 867, 874 (1984); Migra v Warren City School District Board of Education, 465 US 75, $77 \mathrm{n} 1$ (1984); and Jones $v$ City of Alton, 757 F2d 878, 884 (7th Cir 1985).

${ }^{10}$ Brown v Felsen, 442 US 127, 131 (1979); and Adkins v Allstate Insurance Co., 729 F2d 974, 976 (4th Cir 1984) (quoting Restatement (Second) of Judgments § 19, comment a (cited in note 5) ("[F] airness to the defendant, and sound judicial administration, require that at some point litigation over the particular controversy come to an end."). See generally Class $v$ Norton, 505 F2d 123, 125 (2d Cir 1974).

"See Kathios v General Motors, 862 F2d 944, 951 (1st Cir 1988) (emphasizing the "state's disdain for litigatory replays"). For an oft-cited description of the policies justifying claim preclusion, see Edward W. Cleary, Res Judicata Reexamined, 57 Yale L J 339 (1948).

12 Felsen, 442 US at 131.

1s See generally Automatic Liquid Packaging, Inc. v Dominik, 852 F2d 1036 (7th Cir 
consideration of issues actually litigated and necessary to the outcome in a prior suit, ${ }^{14}$ claim preclusion proscribes consideration of all grounds of relief that could have been raised in a prior adjudication, regardless of whether they actually were raised. ${ }^{15}$

The doctrine of claim preclusion binds both parties and their privies to a prior judgment. Suppose Agency A brings a suit against private defendant $D$; agency $B$ would like to sue $D$ on the same transaction. If $A$ and $B$ are in privity, A's suit will bar B's. If it happens that Agency A does not achieve Agency B's particular policy goals, Agency B will nonetheless be unable to pursue those goals through further litigation against $\mathrm{D}$. Therefore, a rational standard for determining agency privity is crucial to achieving a balance between agency goals and claim preclusion policies of finality, consistency, and judicial economy.

\section{Uncertain privity.}

Unfortunately, the courts have not developed a clear formulation of privity among administrative agencies. The term privity itself is largely conclusory; it does not clearly provide a basis "for including or excluding one from the [preclusion] of a judgment. It is merely a word used to say that the relationship between the one who is a party on the record and another is close enough to include that other within the [preclusion]."16 Recognizing the conclusory nature of the term, the Restatement (Second) of Judgments replaced "privity" with the more descriptive phrases "person represented by a party" and "persons affected by a judgment."17 Nevertheless, the extent to which construction of the term privity may expand the binding force of claim preclusion remains unclear.

Although privity has no formal definition, the concept is anchored in several basic considerations. Privity requires a legally cognizable relationship between a party to a completed action and the party to be precluded. In essence, privity requires that the for-

1988); and Henry v Farmer City State Bank, 808 F2d 1228 (7th Cir 1986).

14 Parklane Hosiery, 439 US at 326 n 5; and Cromwell, 94 US at 353. See also Restatement (Second) of Judgments $\S 27$ (cited in note 5).

${ }_{15}$ Felsen, 442 US at 131; and Chicot County Drainage District v Baxter State Bank, 308 US 371, 378 (1940).

${ }_{18}$ Bruszewski v United States, 181 F2d 419, 423 (3d Cir 1950) (Goodrich concurring).

${ }_{17}$ Restatement (Second) of Judgments $\$ 41$ (cited in note 5). See James R. Pielemeier, Due Process Limitations on the Application of Collateral Estoppel Against Nonparties to Prior Litigation, 63 BU L Rev 383, 387-88 (1983); and Restatement (Second) of Judgments at 13-14. The Restatement also notes that the concepts of "transaction" and "claim" have no rigid boundaries. Section 24 , comments a and b. 
mer party represent the latter, ${ }^{18}$ through a congruence of interests. In order to find privity, the court must determine "that the parties in the two actions are really and substantially in interest the same."19 With government agencies, courts can approximate "interests" from an agency's functions and responsibilities. ${ }^{20}$ Thus, a standard of interagency privity should reflect any congruence (or lack thereof) in agency functions and responsibilities.

In addition, privity must comport with the requirements of procedural due process: notice and the opportunity to be heard. ${ }^{21}$ Though claim preclusion denies a party any "right" to litigate, due process requires that the nonparty have sufficient notice of other, "representative" litigation in order to preserve its interests by, for example, joining in the prior action or disputing the adequacy of the representation. ${ }^{22}$ Therefore, an agency should not be precluded

\footnotetext{
${ }^{18}$ See also James W. Moore, Jo Desha Lucas, and Thomas S. Currie, 1B Moore's Federal Practice đ0.411[1] at 390 (Matthew Bender, 2d ed 1984) ("Moore's") ("[P]ersons whose interests are properly placed before the court by someone with standing to represent them are bound by the matter determined in the proceeding.").

10 St. Louis Baptist Temple v FDIC, 605 F2d 1169, 1174 (10th Cir 1979) (privity has been found in cases involving a person so identified in interest with another that he represents the same legal right). See also Carter $v$ City of Emporia, 815 F2d 617, 620 n 3 (10th Cir 1987) (under Kansas law, "privity involves direct representation of the nonparty's interest as distinguished from participation by a nonparty or a nonprivy who cannot or chooses not to intervene"); Hurt v Pullman Inc., 764 F2d 1443, 1448 (11th Cir 1985) (quoting Moore's I 0.411[3.2] at 428 (cited in note 18)) ("where the names are the same but the interests put into litigation belong to others, res judicata follows the interest and not the name") (emphasis in original).

${ }_{20}$ See Restatement (Second) of Judgments $\$ 36$, comment $f$ at 364 (cited in note 5):

If the second action involves an agency or official whose functions and responsibilities are so distinct from those of the agency or official in the first action that applying preclusion would interfere with the proper allocation of authority between them, the earlier judgment should not be given preclusive effect in the second action.

${ }^{21}$ Expert Electric $v$ Levine, 554 F2d 1227, 1233 (2d Cir 1977) ("The threshold requirement of [privity] finds its roots in the ancient notion, now supplemented by the due process clause, that a person cannot be bound by a judgment without notice of a claim and an opportunity to be heard."); Moldovan v Great Atlantic \& Pacific Tea Co., 790 F2d 894, 899 (3d Cir 1986) (citing Hansberry v Lee, 311 US 32, 45 (1940)). See also Pielemeier, 63 BU L Rev at 395-425 (cited in note 17) (detailing the due process underpinnings of the Restatement's analysis of judgments binding nonparties).

${ }^{22}$ See Phillips Petroleum Co. $v$ Shutts, 472 US 797 (1985). In deciding whether an "opt in" procedure is required in class action suits, the court stated:

If the forum State wishes to bind an absent plaintiff concerning a claim for money damages or similar relief at law, it must provide minimal procedural due process protection. The plaintiff must receive notice plus an opportunity to be heard and participate in the litigation, whether in person or through counsel. The notice must be the best practicable, 'reasonably calculated, under all the circumstances, to apprise interested parties of the pendency of the action and afford them an opportunity to present their objections.'
}

Id at 811-12 (footnotes and citations omitted). 
from litigating a claim unless it had sufficient notice of its privity with the first agency to protect the claim.

\section{B. Policy in the Administrative Context}

Any application of claim preclusion to federal agencies must account for certain unique aspects of the federal administrative structure. Some aspects of that structure reinforce the interests underlying traditional claim preclusion, but others conflict.

\section{Size and autonomy.}

Two characteristics of the federal administrative structure are particularly salient to any claim preclusion analysis. First, it is enormous. The Government Manual lists 456 separate agencies appearing in the Code of Federal Regulation. ${ }^{23}$ Each of these 456 agencies pursues its own aspect of federal policy, resulting in a large amount of government litigation. To appreciate the amount of litigation generated by agencies, consider that the federal government was involved in almost 30 percent of the civil cases appealed from the federal district courts to the federal circuit courts in $1982 .{ }^{24}$

Such size and scope help account for a second distinctive aspect of the administrative state, the autonomy ${ }^{25}$ and specialization agencies have acquired. ${ }^{26}$ Agencies pursue their separate, substan-

\footnotetext{
${ }^{23}$ Office of the Federal Register, The United States Government Manual 1988-89 84150 (GPO, 1988).

24 United States v Mendoza, 464 US 154, 160 (1984), citing Administrative Office of the United States Courts, Annual Report of the Director 79, 82 (1982).

${ }^{25}$ This autonomy is controversial, and several presidents have tried to limit it. In 1981, for example, President Reagan issued a pair of executive orders, Numbers 12291 and 12498, directing executive (but not independent) agencies to submit annual plans and all proposed regulations to the Office of Management and Budget ("OMB") for review. 1981 US Code Congressional and Administrative News ("USCCAN"), vol 3 at B4-B10, B15-B17. For commentary on this attempt to control executive agency actions, see Alan B. Morrison, $O M B$ Interference with Agency Rulemaking: The Wrong Way to Write a Regulation, 99 Harv L Rev 1059 (1986); and Christopher C. DeMuth and Douglas H. Ginsburg, White House Review of Agency Rulemaking, 99 Harv L Rev 1075 (1986). OMB review is limited to annual plans and regulations, which do not encompass litigation, so the $\mathrm{OMB}$ does not coordinate or prevent potentially duplicative agency litigation.

For a defense of agency autonomy on constitutional grounds, see Note, In Defense of Administrative Agency Autonomy, 96 Yale L J 787 (1987).

${ }^{28}$ On the relation between the increasing size and increasing autonomy of the federal agencies, see Douglas H. Shumavon and H. Kenneth Hibbeln, eds, Administrative Discretion and Public Policy Implementation 1 (Praeger, 1985):

As the size and complexity of government has [sic] increased, the roles and powers of administrators as actors in the policy-making process have grown significantly .... In the implementation process especially, administrators have become policy makers in
} 
tive public policy goals with little or no coordination. ${ }^{27}$ The executive branch exercises little direct control over agency litigation, ${ }^{28}$ and courts are reluctant to interfere with agencies' pursuit of their missions. ${ }^{28}$ Though the Department of Justice has the primary authority to conduct and coordinate litigation on behalf of the federal government and government bodies, ${ }^{30}$ at least thirty-five agencies have some independent litigation authority. ${ }^{31}$

Although autonomous agencies pursue separate substantive goals, more than one agency may be entitled to act on a given matter. For example, both OSHA, in its pursuit of safe workplaces, and the EPA, in its pursuit of a healthy environment, regulate the emission of benzene. ${ }^{32}$ When one agency pursues a goal in a different fashion than another agency charged with a related task, a private party defendant may face repetitive if not inconsistent government actions.

\section{Precluding agency action.}

The application of claim preclusion to agency actions implicates complex and often conflicting interests. First, the harm to

their own right, often enjoying virtual autonomy as they exercise discretionary authority accorded to them by legislative and executive institutions.

${ }^{27}$ See id; and Theodore J. Lowi, The End of Liberalism: The Second Republic of the United States 67-126 (Norton, 2d ed 1979).

${ }^{28}$ See Griffin B. Bell, The Attorney General: The Federal Government's Chief Lawyer and Chief Litigator, or One Among Many?, 46 Fordham L Rev 1049, 1057-69 (1978). For a history of the effort to coordinate government litigation in the Justice Department, see Charles Tiefer, The Constitutionality of Independent Officers as Checks on Abuses of Executive Power, 63 BU L Rev 59, 70-85 (1983).

${ }^{29}$ See McKart v United States, 395 US 185, 194 (1969) ("The administrative agency is created as a separate entity and invested with certain powers and duties. The courts ordinarily should not interfere with an agency until it has completed its action, or else has clearly exceeded its jurisdiction.").

so 28 USC \& 516 (1982).

${ }^{31}$ Susan M. Olson, Challenges to the Gatekeeper: The Debate over Federal Litigation Authority, 68 Judicature 70, 73 (1984) (agency count as of 1982). Agencies may not conduct litigation on their own without congressional authorization. 5 USC $\S 3106$ (1982).

To give the Attorney General more control over litigation, Executive Order 12146, 3 CFR 409 (July 18, 1979), created the Federal Litigation Council, chaired by the Attorney General and including representatives from fifteen agencies. The Order did little to change autonomous agency behavior. It did not require agencies to reduce duplicative litigation, but merely established a notice system to facilitate communication, $\S 1-302$, and only applied to the fifteen agencies designated in § 1-102. See Dean v Harrington, 668 F Supp 646, 652-53 (E D Tenn 1987) (holding that the Order does not apply to the Tennessee Valley Authority). Finally, under the Reagan Administration, the Council focused on litigation policy, not coordination. Although the Council has been expanded to include representatives from all agencies, it has been characterized as merely an "opportunity for the general counsels to get to know each other." Olson, 68 Judicature at 77.

${ }^{32}$ See $29 \mathrm{CFR} \S 1910.1028$ (1988); and $40 \mathrm{CFR} \S 712.30$ (1988). 
private parties of repetitious litigation supports preclusion. Second, the inability of the government to assert a coordinated defense to repetitious private party suits also favors preclusion. When the government is a defendant, the size and autonomy of the administrative structure may encourage private parties to initiate multiple suits against different agencies, thereby burdening the resources of courts and administrative forums. Third, the traditional finality, consistency, judicial economy, and fairness rationales underlying claim preclusion apply in the administrative context as well.

Counseling against strict application of claim preclusion to agencies is, among other things, the need to preserve each agency's autonomy in pursuing distinct policy goals. As a general matter, courts exhibit a degree of deference to agencies' special mission. For example, under doctrines such as the requirement of exhaustion of administrative remedies, courts recognize congressional reliance on agency expertise in certain areas of public policy. ${ }^{33}$ Courts seek "to avoid premature interruption of the administrative process, thereby preserving the integrity and autonomy of the agency-particularly where the administrative agency has vested in it discretionary powers or is intended to apply its expertise to the problem before it." ${ }^{\text {"34 }}$ This need to preserve agency autonomy conflicts with strict administrative claim preclusion.

Other factors have influenced the courts' application of claim preclusion to agencies. Courts have recognized the power of Congress to limit the preclusive effect that administrative decisions ${ }^{35}$

ss Weinberger v Salfi, 422 US 749, 765 (1975) ("Exhaustion is generally required as a matter of preventing premature interference with agency processes, so that the agency may function efficiently and so that it may have an opportunity to correct its own errors, to afford the parties and the courts the benefit of its experience and expertise."); Lavallee Northside Civic Association v Virgin Islands Coastal Zone Management Commission, 866 F2d 616, 620 (3d Cir 1989); Lyons v U.S. Marshals, 840 F2d 202, 204-05 (3d Cir 1985) (noting that two policies underlying the exhaustion doctrine are "deference to Congress" decision ... that an independent administrative tribunal ... should serve as the initial forum for dispute resolution" and "respect for administrative autonomy . . . .")(citations omitted); and Ticor Title Insurance Co. v FTC, 814 F2d 731, 755 (DC Cir 1987) ("Since administrative agencies, as autonomous bodies, always have an interest in avoiding judicial interruption of their proceedings, courts require some showing of hardship to warrant judicial intrusion into the agency's domain, even where the issues are otherwise generally fit for review.").

${ }^{34}$ United States ex rel Brooks v Clifford, 412 F2d 1137, 1138 (4th Cir 1969).

ss Freedom Savings \& Loan Association v Way, 757 F2d 1176, 1180 (11th Cir 1985) (recognizing congressional intent to limit the "res judicata or collateral estoppel" effect of the Trademark Trial and Appeal Board because of the need for "extensive judicial involvement in the registration and protection of trademarks") (citing Alexander v Gardner-Denver Co., 415 US $36,48-51$ \& n 10 (1974)). 
and court decisions have on subsequent administrative action. ${ }^{36}$ At other times, courts have skirted applying claim preclusion when doing so would result in manifest injustice. ${ }^{37}$ The consensus seems to be that claim preclusion applies much less rigidly to administrative decisions than to court decisions. ${ }^{38}$ Due process considerations are also important to analyzing claim preclusion in the administrative context. Due process requires that nonparties be given notice and an opportunity to participate in a suit before the judgment in that suit can bind them. ${ }^{39}$ The lack of formal coordination among autonomous agencies increases the costs of obtaining notice of the litigation activities of other agencies. Autonomy also increases an agency's costs of acting upon this notice to preserve its interests. The agency must either give up some autonomy by accelerating its litigation activities to join in the actions of other agencies, or risk losing any subsequent right to address certain claims.

Autonomy also makes it difficult to assess the adequacy of representation of agency interests. Since agencies pursue separate and distinct policies, courts have trouble determining when two agencies' interests and responsibilities in a given action are similar enough to invoke preclusion. Any standard of privity, therefore, must protect an agency's substantive policy interests, minimize the costs of obtaining and acting upon notice, and include a coherent method of ensuring adequate representation.

${ }^{36}$ Alexander $v$ Gardner-Denver Co., 415 US 36, 48-51 \& n 10 (1974) (recognizing congressional intent to allow a de novo action by the Equal Employment Opportunity Commission despite an earlier, potentially preclusive arbitration action, because of a policy of "allow[ing] an individual to pursue independently his rights under both Title VII and other applicable state and federal statutes.")

37 Purter $v$ Heckler, 771 F2d 682, 691 (3d Cir 1985) ("Rigid application of [res judicata] must be tempered by fairness and equity. ..."); and Thompson $v$ Schweiker, 665 F2d 936, 940-41 (9th Cir 1982) ("Both [issue and claim preclusion] are qualified or rejected when their application would contravene an overriding public policy or result in manifest injustice.") (quoting Tipler v E.I. duPont deNemours and Co., 443 F2d 125, 128 (6th Cir 1971).

${ }^{38}$ See, for example, Chavez $v$ Bowen, 844 F2d 691, 693 (9th Cir 1988); Facchiano, 859 F2d at 1167; and Purter, 771 F2d at 691.

s9 Administrative agencies, as parts of the government, would not seem to have life, liberty, or property interests within the meaning of the Fifth and Fourteenth Amendments. Nonetheless, due process concerns are a useful proxy for protecting the substantive missions of agencies. See Deborah Maranville, Nonacquiescence: Outlaw Agencies, Imperial Courts, and the Perils of Pluralism, 39 Vand L Rev 471, 516 (1986) ("In the traditional sense, an administrative agency has no 'rights' that will be affected by an agency adjudicative hearing. Practically speaking, however, the decision resulting from an administrative hearing may affect substantially the parameters within which the agency must operate. In that sense, administrative proceedings may affect the agency's right to take certain actions.") (emphasis added). 
In sum, the unique characteristics of the administrative state-the extent of agencies' autonomy and the scope of their activities-intensify the reasons both for and against applying claim preclusion to administrative agencies. The increased potential for duplicative litigation increases the finality and judicial economy concerns behind claim preclusion, while agencies' special need to pursue mandated policy initiatives with minimal interference introduces a new concern advising against preclusion. A workable concept of interagency privity must balance these competing interests.

\section{Various Approaches to Interagency Privity}

In evaluating claim preclusion against agencies, courts have yet to develop a standard of privity that considers all the relevant policies. Two approaches to interagency privity dominate: the rigid Sunshine rule and the overly flexible ad hoc approach.

\section{A. The Sunshine Rule}

1. Basis of the rule.

In Sunshine Anthracite Coal Co. $v$ Adkins, ${ }^{40}$ Sunshine sought to enjoin the Internal Revenue Service ("IRS") IRS from collecting taxes on its coal even though a prior action against the National Bituminous Coal Commission ("NBCC") had determined that the coal was taxable. The Court held that the prior NBCC determination of the coal's status bound all other government agencies, stating:

There is privity between officers of the same government so that a judgment in a suit between a party and a representative of the United States is res judicata in relitigation of the same issue between that party and another officer of the government. ${ }^{41}$

With this broad language, the Court declared that all federal agencies are in privity, a standard that five circuits continue to follow. ${ }^{42}$

40 310 US 381 (1940).

41 Id at 402-03. As discussed below, the language speaks in terms of issue preclusion, but some courts have followed the Sunshine rule in claim preclusion cases.

12 See Walsh v International Longshoremen's Assn., 630 F2d 864, 870 (1st Cir 1980); Safir v Gibson, 432 F2d 137, 142-43 (2d Cir 1970); Schuster v Martin, 861 F2d 1369, 1373 n 7 (5th Cir 1988) (using Sunshine rule to find that state employees and agencies are in privity); Boone v Kurtz, 617 F2d 435, 436 (5th Cir 1980); Scott v Kuhlmann, 746 F2d 1377, 1378 (9th Cir 1984); and Environmental Defense Fund v NRC, 866 F2d 1263, 1269 (10th Cir 1989) (implicitly following Sunshine by declaring that EPA and NRC are in privity as mem- 
To its credit, the rule is simple, but its breadth and inflexibility disserve agency interests and due process concerns. Consequently, the courts have employed a variety of techniques to limit the sweep of the rule. ${ }^{43}$ Some courts have permitted the second agency's suit by finding that another element of claim preclusion, such as the existence of a single transaction, is missing. ${ }^{44}$ Other courts have found that the potential "injustice" resulting from an inflexible application of the Sunshine rule warrants abandonment of claim preclusion altogether in the administrative context. ${ }^{45}$

The circuits are also split on whether the Sunshine rule even applies to claim preclusion. While five circuits hold that it does, ${ }^{46}$ three now contend that Sunshine should be limited to the narrower doctrine of issue preclusion that was directly involved in the cases. ${ }^{47}$ As this latter group of courts points out, though in its opinion in Sunshine the Court used the term "res judicata" in its broad sense, which includes both claim and issue preclusion, the question in the case was whether the IRS could relitigate the same issue that the NBCC had litigated-the tax status of Sunshine's coal. ${ }^{48}$ Under this second group's interpretation, the Sunshine rule bars agencies from relitigating those issues actually litigated in a previous suit by another agency, but does not preclude agencies from raising claims that could have been raised in a prior action.

\section{Application of the rule.}

Applying the Sunshine rule to claim preclusion in the administrative context would require each agency to undertake the Her-

\footnotetext{
bers of the "federal executive branch"). Until recently, the Third, Seventh, and Eighth Circuits also followed Sunshine. See United States v Athlone Industries, Inc., 746 F2d 977, 983 n 5 (3d Cir 1984) (tacitly applying a Sunshine-like approach); Mandarino v Pollard, 718 F2d 845, 850 (7th Cir 1983) ("A government and its officers are in privity for purposes of res judicata."); and River Valley, Inc. v Dubuque County, 507 F2d 582, 586 (8th Cir 1974). Compare the cases cited in note 47 , limiting or abandoning the Sunshine rule.

${ }^{43}$ Napier $v$ Thirty or More Unidentified Federal Agents, 855 F2d 1080, 1086-87 n 2 (3d Cir 1988) (avoiding privity issue by deciding case on statute of limitations grounds); The Evergreens $v$ Nunan, 141 F2d 927 (2d Cir 1944) (adopting the now-discredited distinction between mediate and ultimate facts to avoid a finding of privity).

4t See, for example, Athlone Industries, 746 F2d at 983 n 5 (finding privity, but deciding that the suit was not precluded because it was brought on a different cause of action).

t5 See text at notes 37-38.

${ }^{48}$ See, for example, Scott, 746 F2d at 1378. The First, Second, Fifth, Ninth, and Tenth Circuits apply Sunshine in claim preclusion cases. See cases cited in note 42.

47 These include the Third, Seventh, and Eighth Circuits. Napier, 855 F2d at 1086-87 n 2; Headley v Bacon, 828 F2d 1272, 1277 (8th Cir 1987); Beard v O'Neal, 728 F2d 894, 897 (7th Cir 1984); and Conner v Reinhard, 847 F2d 384, 396 (7th Cir 1988).

t8 Sunshine, 310 US at 390-91.
} 
culean task of monitoring all other government litigation. Furthermore, the timing and strategy of an agency's litigation is a large part of that agency's implementation of its mandated policies. A sweeping standard of privity frustrates congressional intent by requiring all agencies potentially interested in a single transaction to join in one action to preserve their claims, regardless of the agencies' preparedness or the uniqueness of their missions.

Finally, a standard holding all government agencies in privity fails to consider whether multiple litigation is intended or serves public policy. The Sunshine rule assumes that multiple government litigation is bad per se. While perhaps appropriate in the 1930s when agencies were fewer and less autonomous than they are today, the rule creates major monitoring and coordination costs in a modern governmental structure that grants many agencies independent litigation authority. It prevents courts from balancing the competing interests unique to agency litigation, and requires the courts to devise exceptions and limitations to the rule in order to avoid the harshness that flows from widespread preclusion.

\section{B. Ad Hoc Determinations of Interagency Privity}

The three circuits that limit the Sunshine rule to issue preclu$\operatorname{sion}^{49}$ have nonetheless failed to articulate a coherent standard of interagency privity. These courts have taken an ad hoc approach to claim preclusion, focusing the analysis of interagency privity on two factors: congruence of interests and agency authority. These factors, however, share the same flaws as the traditional concept of privity; they are merely conclusory. ${ }^{50}$

The first factor in the ad hoc approach, congruence of interests, inquires whether the interests of the agency to be precluded in the present litigation are the same as those of the agency in the prior litigation. For example, in Headley $v$ Bacon, the Eighth Circuit used agency interests to decide whether police officers were in privity with the city in two separate suits alleging the wrongful discharge of a police officer. ${ }^{51}$ The court noted three differences between the claims in the two suits: (1) the first (against the city)

40 See text at notes $46-47$.

so See text at note 16 .

s1 828 F2d 1272 (8th Cir 1987). In the first suit (against the city), the court awarded damages under Title VII. The subsequent suit against the police officers was under 42 USC $\S \S 1982,1983$, and 1985 and alleged violation of due process, equal protection, and First Amendment rights. Because of the similarity of the allegations in the two suits, the district court found privity and granted summary judgment against the police officers. 
resulted in equitable relief while the second (against the officers) sought compensatory and punitive damages; (2) the second provided a right to a jury trial while the first did not; and (3) the claims provided the police and the city with contradictory defenses. After listing these differences in interests, however, the court failed to analyze their significance. Instead, it merely asserted that the difference in interests was sufficient to overturn the district court's finding of privity. ${ }^{52}$ The court gave no guidance on how to measure or balance these interests; nor did it indicate whether other interests might be significant in other cases. Instead of articulating a method to determine privity, the court merely restated a traditional aspect of privity, the congruence of interests. ${ }^{53}$

The second factor used in ad hoc analysis is agency authority: Does the agency in the first suit have the authority to act on behalf of the agency in the second suit? ${ }^{54}$ But here, as with the congru- ence of interests inquiry, the courts provide no guidance for identifying or measuring this authority. In Headley, the Eighth Circuit pointed out that the police officers "were not in such clearly policymaking positions as to be the same sort of 'voice and hand' of a municipality as its elected governing officials." ${ }^{55}$ Using the same authority rationale, the Fourth Circuit found that a state university's president, chancellor, and dean-as agents with authority to act on behalf of the school's board of regents-were in privity with the board, so that an earlier state discrimination action against the board barred further Title VII litigation against the officers. ${ }^{68}$ Neither court gave clear reasons for its conclusion that one governmental entity had or lacked authority to represent another.

The congruence of interests and agency authority inquiries impede proper analysis of interagency privity. A court that resorts to "identity of interests" to determine privity without explaining these interests fails to provide agencies with notice of potential preclusion. In addition, an analysis of agency authority, even if technically feasible, seems incompatible with a federal administrative structure characterized by autonomous agencies pursuing sep-

52 Headley, 828 F2d at 1279-80.

s3 See text at notes 18 and 19.

34 Note that Sunshine planted the seed for an "agency authority" approach:

The crucial point is whether or not in the earlier litigation the representative of the United States had authority to represent its interests in a final adjudication of the issue in controversy.

$310 \mathrm{US}$ at 403.

ss Headley, $828 \mathrm{~F} 2 \mathrm{~d}$ at 1276.

${ }^{s 8}$ Kutzik $v$ Young, 730 F2d 149, 152 (4th Cir 1984). 
arate and distinct missions. ${ }^{57}$ Since each federal agency has its own separate policy goals, a standard of privity based on "authority to act for others" may result in little or no preclusion at the federal level.

\section{Approaches Suggested by Commentators}

Despite the weaknesses of existing judicial approaches to interagency privity, few legal scholars have addressed the problem. One commentator has suggested that agencies be held in privity only when they answer to a common superior and are litigating for non-regulatory purposes. ${ }^{58}$ While some duplicative executive agency litigation that could be coordinated by superiors would be curtailed by this approach, ${ }^{59}$ the approach exempts all independent agencies from interagency preclusion. While the Sunshine approach precludes too many agencies, the common authority approach precludes too few.

A second commentator ${ }^{60}$ has proposed that for each single claim in which multiple agencies are interested, courts stay all but one action. Courts would avoid ex post questions of interagency claim preclusion by choosing the agency with the greatest expertise to litigate the claim on behalf of the government. The court would base its choice of agency on an extension of the primary jurisdiction doctrine, under which courts stay judicial cases until the agency with the greatest expertise decides the administrative issues. ${ }^{81}$

This extended primary jurisdiction approach is also troublesome. First, it would block the litigation activities of all but the "chosen" agency, possibly frustrating the policy interests that the

s7 See text at notes 27-32.

so Note, Res Judicata and Intra-governmental Inconsistencies, 49 Colum L Rev 640 , 650-61 (1949). Non-regulatory purposes primarily involve fiscal activity, such as collecting back taxes. Id at 651-53. This restriction is intended to prevent claim preclusion from interfering with the important policy interests that drive agency litigation.

60 The Department of Justice does coordinate the litigation of those agencies for which it acts as litigation counsel, but Congress has increased the independent litigation authority of some agencies. See text at notes 27-31.

- Note, Res Judicata and Administrative Jurisdiction-A Proposal for Resolving Conficts Between Agencies with Overlapping Jurisdiction, 35 Geo Wash L Rev 1056, 106367 (1967).

-1 See United States $v$ Western Pacific Railroad Co., 352 US 59 (1956). Primary jurisdiction "applies where a claim is originally cognizable in the courts, and comes into play whenever enforcement of the claim requires the resolution of issues which, under a regulatory scheme, have been placed within the special competence of an administrative body; in such a case the judicial process is suspended pending referral of such issues to the administrative body for its views." Id at 64. 
"unchosen" agencies seek to realize through litigation. If the "chosen" agency decides not to litigate, no agency may litigate with respect to the disputed transaction. Second, this approach would require courts to review the jurisdiction of every potentially interested agency before any agency could litigate a case, resulting in more judicial intrusion in administrative policy than current law and the interests of finality and agency autonomy would allow. ${ }^{62}$

Despite their inability to solve the interagency privity problem, these commentators do provide important insights. Both underscore the harshness and undesirability of the Sunshine rule and, in contrast to the ad hoc approach, both attempt to develop a principled mechanism for limiting interagency privity. The common authority approach attempts to resolve the problem of obtaining notice of potential preclusion within the existing administrative structure. The extended primary jurisdiction approach addresses the root problem of overlapping agency jurisdiction. Both approaches underscore the need for a standard of privity that comports with the realities of the existing administrative structure instead of placing too much hope in radical departures from existing law.

\section{Suggestion: A Specific OverLap Approach}

An approach combining the virtues of these competing solutions is the "specific overlap" approach. Under this approach, courts would look for any overlapping jurisdiction from the statutes and regulations that govern agencies. If the operative lan-

${ }^{82}$ The commentator suggesting this approach relies on a proposed amendment to the Administrative Procedure Act, 5 USC \$§ 551 et seq (1982) ("APA"). Note, 35 Geo Wash L Rev at 1065 (cited in note 60). At the time the note was published, Congress was considering amending the APA to provide that: "[A]ny agency proceeding or investigation not within the jurisdiction delegated to the agency and authorized by law upon a showing of irreparable injury may be enjoined by any court of competent jurisdiction." Id at 1066, citing S 518, 90th Cong, 1st Sess $\$ 9(a)(1967)$. This suggests that a court could, upon a-challenge to agency jurisdiction, determine which agency has primary jurisdiction prior to any administrative action. that:

Congress did not approve this amendment, however, and at present the APA provides

Agency action made reviewable by statute and final agency action for which there is no other adequate remedy in a court are subject to judicial review. A preliminary, procedural, or intermediate agency action or ruling not directly reviewable is subject to review on the review of the final agency action.

APA, 5 USC $§ 704$ (1982) (emphasis added). Absent a statute allowing judicial determination of primary jurisdiction prior to any agency action, a court's application of the extended primary jurisdiction approach would violate the interests of finality and expertise embodied in the APA. 
guage of the statutes or regulations under which the cases were brought gives both agencies authority over a specific factual situation, the judge should find privity. Claim preclusion would thus occur only when more than one agency is authorized to act in a specifically described situation. For example, federal legislation empowers both the Federal Trade Commission ${ }^{63}$ and the Department of Justice ${ }^{64}$ to bring suit to prevent the sale of falsely labelled foods. Since both agencies specifically regulate the sale of falsely labelled foods, a specific overlap approach would hold the two agencies in privity with respect to cases involving the sale of such foods.

In some instances, however, the operative language of the governing rules only gives the agencies authority over general factual situations, and agency interests may only loosely overlap. General overlap exists where the litigation of the agencies would not have crossed paths but for some unique event or a long attenuated series of events. ${ }^{65}$ If a transaction interests more than one agency but fits the general language of the governing rules only by coincidence, the agencies are not in privity. For example, both the Environmental Protection Agency ("EPA") and the Department of Transportation ("DOT") might investigate an overturned truck that discharged hazardous liquids. The only reason the EPA, with authority to regulate hazardous liquids, and the DOT, with authority to regulate trucks, would be interested in the same transaction is because the truck carried the liquids. If a factory discharged the liquids, the DOT would not have been involved; if the overturned truck carried water instead of hazardous liquids, the EPA would not have been involved. The EPA and DOT authority to investigate the accident only coincidentally overlaps, and the two agencies should not be found in privity.

The specific overlap approach minimizes the costs of obtaining notice of potential preclusion and ensures adequate representation of agency interests. It limits the scope of privity to those agencies whose separate authorities specifically overlap, giving them concurrent responsibilities over and congruent interests in a specific type of transaction. The specific overlap approach precludes a finding of privity where concurrent responsibilities are merely coincidental. In planning litigation, agencies thus need only monitor those other

63 Federal Trade Commission Act, 15 USC $\$ \S 52,53$ (1982).

64 Federal Food and Drugs Act, 21 USC $\S 16$ (1982).

65 See text at notes 79-90, discussing FTC $v$ Texaco, $555 \mathrm{~F} 2 \mathrm{~d} 862$ (DC Cir 1977) and Facchiano v United States Department of Labor, 859 F2d 1163 (3d Cir 1988). 
agencies with organic statutes or regulations that empower them to deal with the same specific transactions.

The governing statutes and regulations provide an objective basis for an agency to determine ex ante which other agencies are its privies, without waiting for an ex post, possibly conclusory judicial determination of primary jurisdiction and without monitoring the litigation of countless other agencies. Although existing concepts of agency interest and congruence of interests elude definition, the specific situations addressed by the statutes and regulations empowering agencies to litigate can serve as proxies, just as the relationships described in a contract provide an objective method of determining privity. ${ }^{66}$

\section{A. Case Law Hypotheticals}

This section applies the specific overlap standard to several factual situations and different statutes and regulations. The examples are drawn from actual cases in which one agency's action could arguably preclude another agency's suit. The section will also compare the outcomes under the specific overlap approach with the outcomes dictated by rigorous application of the Sunshine rule. ${ }^{67}$

\section{Specific overlap: agency plaintiffs.}

The first example draws on the factual situation and administrative posture that gave rise to the Sunshine rule. ${ }^{68}$ In 1937 , Congress passed the Bituminous Coal Act (the "Act"), ${ }^{69}$ which enabled the National Bituminous Coal Commission ("NBCC") to regulate coal prices and impose certain taxes on coal producers. In August 1938, the NBCC held that Sunshine was subject to the regulations promulgated under the Act and therefore would have to pay taxes on its coal. ${ }^{70}$ Completely apart from this litigation, the IRS insti-

68 See text at note 20 .

67 Specific case examples were chosen because the agencies and disputes involved illustrate well the distinctions between the Sunshine rule and the specific overlap approach to interagency privity. Most of these cases were not ultimately decided on claim preclusion grounds, either because the parties did not raise the issue or because the courts did not rigorously apply claim preclusion given the inflexibility of the Sunshine approach. See text at notes $43-45$.

${ }^{68}$ Justice Douglas relates the facts and procedural history of the case at 310 US at 387 91.

68 See 15 USC $\S \S 828-52$ (1937). The sections involved in this discussion were repealed on September 6, 1966 by Pub L No 89-554, §8(a), 80 Stat 649, 651 (1966).

${ }_{70}$ This ruling was affirmed in Sunshine Anthracite Coal Co. $v$ National Bituminous 
tuted an action to collect the taxes Sunshine owed under the Act. The Supreme Court reviewed this second action in Sunshine Anthracite Coal Co. $v$ Adkins, noted above for its broad definition of privity. ${ }^{71}$

For purposes of this example, suppose that the IRS and NBCC claims arose from a single transaction, Sunshine's coal production, and that both the NBCC and the IRS were trying to fine Sunshine for not complying with the Act. ${ }^{-72}$ If claim preclusion did apply, the Court could bar the IRS action because the claim for tax revenues would merge into the judgment in the NBCC action.

The only question left in determining whether Sunshine has a valid claim preclusion defense is whether the IRS and the NBCC are in privity. Under the Sunshine approach, the agencies are in privity because they are part of the federal government. Under the specific overlap approach also, the agencies are in privity. The Act contains the statutory provisions authorizing both the IRS and NBCC actions. Both provisions, therefore, address the same factual situations. The governing statute would have provided the IRS with notice that it must monitor the NBCC's litigation activity and institute single actions covering both the regulatory and tax claims. Consequently, the IRS would have been required to raise its claim for taxes in the prior NBCC action or suffer preclusion.

The statute in this example illustrates well the concurrent responsibilities and interests of the two agencies. Since the statute applies to the IRS and the NBCC, both agencies are pursuing the same substantive policies-those embodied in the Act. One agency could adequately represent the other's interests in penalizing Sunshine for its noncompliance. The shared governing statute is a cost-effective method of providing notice of potential preclusion. The finding of privity is therefore supported by the policy considerations previously discussed, and there is no reason to subject Sunshine to repetitive litigation.

Coal Commission, 105 F2d 559 (8th Cir 1939).

71 See text at notes 40-48.

72 It is not clear whether the NBCC decision to regulate Sunshine and the IRS collection action arose from the same transaction. If, instead of trying to collect the back taxes deemed recoverable in the NBCC action, the IRS was trying to collect a fine for prior noncompliance with the Bituminous Coal Act, then the two actions seem more likely to have arisen from a single transaction. 
2. Specific overlap: agency defendants.

The specific overlap approach can also determine interagency privity when a case, or a series of cases, involves a private plaintiff and agency defendants. In Mervin v FTC, ${ }^{73}$ the DC Circuit decided that a claim for wrongful discharge against the Civil Service Commission ("CSC") precluded a subsequent claim against the Federal Trade Commission ("FTC"). ${ }^{74}$ The FTC had discharged the plaintiff, Mervin, as part of a workforce reduction. Mervin appealed his discharge to the CSC, alleging that the FTC had not followed its own regulations. The FTC's administrative regulations gave it authority over workforce reductions, ${ }^{75}$ and the Code of Federal Regulations gave the CSC authority to investigate government discharges resulting from reductions in force. ${ }^{76}$ When the CSC declined to hear Mervin's appeal, he petitioned the district court for the District of Columbia to direct the CSC to consider the appeal on its merits. The court dismissed his action for failure to state a claim. ${ }^{77}$ Later, Mervin brought a suit directly against the FTC for violating its regulations and the Due Process Clause of the Fifth Amendment. On appeal, the DC Circuit found that claim preclusion barred the second action because Mervin's claims against the FTC arose from the same transaction as his claims against the CSC, and under the Sunshine approach the FTC and CSC would be in privity as two agencies of the federal government. ${ }^{78}$

The specific overlap approach would yield the same result. Since the regulations giving rise to claims against both the FTC and the CSC concern an FTC workforce reduction discharge, the agencies would be deemed in privity. The regulations contemplate the same specific factual pattern, and therefore the interests of the FTC and the CSC are congruent. One can infer from the statutes that CSC, with authority over all government discharges, was an adequate representative of the FTC's interest in litigating an FTC employee discharge suit, and the statutes provide adequate notice of potential overlapping responsibilities. Therefore, the agencies

\footnotetext{
${ }^{73} 591$ F2d 821 (DC Cir 1978).

:4 The functions performed by the CSC are now undertaken by the Office of Personnel Management.

${ }^{75}$ See Mervin, 591 F2d at 829, citing FTC Administrative Manual, § 5-430.22.

${ }^{78}$ See Mervin, 591 F2d at 830.

${ }^{77}$ Id, citing Mervin v United States Civil Service Comm'n, No 74-1297 (D DC, August 24, 1974).

${ }^{78}$ Mervin, 591 F2d at 530-31.
} 
should be in privity and should be entitled to assert a defense of claim preclusion.

3. Coincidental overlap: antitrust.

Coincidental overlap, which does not result in privity under the specific overlap approach, is exemplified by the regulations at issue in FTC $v$ Texaco. ${ }^{79}$ Since 1945, the American Gas Association ("AGA"), a trade association representing producers, distributors, and marketers of natural gas, has been providing estimates on the levels of gas reserves. In 1969, shortly after a Federal Power Commission ("FPC") order reevaluating gas prices, the AGA reported the first decline in Southern Louisiana reserves. After a series of reviews pursuant to the Natural Gas Act, ${ }^{80}$ which authorizes the FPC to regulate natural gas prices, the FPC ruled that the AGA data was reliable for rate-making.

The report of a decline in gas reserves led AGA members to raise their rates. The increase in rates prompted the FTC to institute an investigation into possible collusion by the AGA in promoting unfair trade. The AGA refused to cooperate with the FTC's subpoenas in this second investigation, and the trial court held that the prior FPC action finding the AGA data valid precluded the FTC from investigating the issue of whether the data evidenced collusion. ${ }^{81}$ The DC Circuit reversed on the ground that the FTC's antitrust investigation could not be precluded. The court noted that the courts did not have the power to speculate about what issues FTC had to investigate, ${ }^{\mathbf{8 2}}$ and while AGA's data was valid for FPC's ratemaking purposes, the data could still be questionable in the antitrust context.

Under the Sunshine approach, the court would find the FTC and FPC in privity since both are government agencies. Yet the two clearly had separate interests in the AGA report. The FPC was primarily concerned with the accuracy of the gas rates; the FTC sought to determine whether the gas rates were part of a scheme of

78555 F2d 862 (DC Cir 1977). The DC Circuit actually decided Texaco on issue preclusion grounds, but claim preclusion arguably applied as well. Both the majority and dissenting opinions provide a detailed history of the case. See Texaco, 555 F2d at 866-71 and 89598.

so 15 USC § 717(d) (1982). See Area Rate Proceeding (Southern Louisiana Area), 40 FPC 530 (1968).

${ }^{81}$ Texaco, $555 \mathrm{~F} 2 \mathrm{~d}$ at 878.

${ }^{82}$ Id at 880 . Although the discussion in the opinion revolves around issue preclusion, the facts present a colorable claim preclusion defense. Here, the FTC and FPC launched investigatory inquiries into the AGA report. 
collusion. Despite these differences in interest, the Sunshine approach would arbitrarily find privity.

Under the specific overlap approach, however, the FTC and the FPC would not be in privity, because the statutes authorizing their respective actions do not concern the same specific factual situations. The Natural Gas Act authorizes the FPC to investigate and set natural gas rates. The Federal Trade Commission Act, ${ }^{83}$ which empowers the FTC "to prevent [certain parties] from using unfair methods of competition in or affecting commerce and unfair or deceptive acts or practices in or affecting commerce,"84 authorizes the investigation into possible AGA collusion. These statutory provisions do not address the same specific factual situation. The FPC would set natural gas rates even if no unlawful collusion warranted FTC action, and the FTC frequently investigates collusion that does not involve natural gas rates. The general factual situations addressed by the statutes overlap only coincidentally. Consequently, the FTC is not in privity with the FPC, and the FTC claims of unlawful collusion should not be precluded by a prior FPC action to fix natural gas rates. ${ }^{85}$

\section{Coincidental overlap: debarment.}

Facchiano $v$ United States Department of Labor ${ }^{86}$ provides another example in which the suggested approach dictates a different result than the Sunshine rule. In 1984, the Department of Labor ("DOL") investigated a construction project conducted by the Facchiano Construction Company and funded by the Department of Housing and Urban Development ("HUD") under the Community Development Block Grant Program ("CDBG"). The DOL's investigation disclosed that Facchiano had covered up the payment of unlawful wages to employees on the project, ${ }^{87}$ and led to the conviction of the company and one of its principals for mail fraud.

${ }^{83} 15$ USC $\$ 41$ et seq (1982).

84 Id at $\S 45(\mathrm{a})(2)$.

so Both the defendants and the dissenting judges argued for issue preclusion based on a primary jurisdiction analysis. Texaco, 555 F2d at 923-26. Since "[t]he Power Commission is the federal agency with special technical and scientific expertise on factual issues involving the oil and gas industry," the FTC should have been precluded from investigating the rates. Id at 925-26 (Wilkey dissenting) (emphasis in original).

86 859 F2d 1163 (3d Cir 1988).

87 The Davis-Bacon Act, 40 USC $\$ 276(\mathrm{a})$ (1982), and the Contract Work Hours and Safety Standards Act, 40 USC $\$ \S 327-32$ (1982), require that workers employed under a government contract be paid specified minimum wages. These statutes also require that employer/contractors report employee wages to the DOL. 
In May 1985, HUD initiated an action to debar Facchiano from the CDBG contract in response to the mail fraud convictions. Debarment is authorized when a contractor has "been convicted of crimes committed in the pursuit, the attempt to pursue, or the performance of public or private contracts, where the conviction(s) have put the contractors' integrity in doubt or where the conduct involved is deemed 'serious' by the Assistant Secretary of HUD."'88 As a result, HUD debarred the company from all HUD contracts for 18 months based on the 1984 mail fraud conviction. Also in 1986, the DOL tried to impose a second debarment from all government contracts for three years pursuant to a regulation empowering it to debar government contractors for violations of the Davis-Bacon Act and other regulations. ${ }^{89}$ Rather than submit to the second proceeding, Facchiano sought an injunction precluding the second debarment.

Although the Third Circuit held that the injunction could not be issued because Facchiano had not exhausted its administrative remedies, ${ }^{90}$ this case does present a colorable claim preclusion defense. Since both the HUD and DOL debarment actions stemmed from false wage reporting, the DOL's claim for debarment would be precluded by the HUD debarment if HUD and the DOL are in privity.

Contrary to the outcome compelled by the Sunshine rule, the agencies would not be in privity under the specific overlap approach. Although both sets of regulations involve debarment and government contracts, the specific factual situations they cover differ. The HUD regulations authorize debarment for criminal convictions related to the performance of a HUD contract, regardless of whether the convictions arose from violations of the Davis-Bacon Act. The DOL regulations require Davis-Bacon Act violations-but not necessarily convictions-for debarment. In addition, the scope of the debarment the two agencies were authorized to impose differed. HUD could only debar a contractor from HUD contracts, while the DOL could bar a contractor from all government contracts. That both regulations apply to the facts of Facchiano is mere coincidence; the agencies lack the congruence of interests present in the Sunshine and Mervin hypotheticals. Therefore, even though DOL may have known that HUD would try to debar Facchiano, HUD could not have adequately represented DOL ab-

\footnotetext{
88 Facchiano, 859 F2d at 1165, citing 24 CFR $\$ \S 24.6(a)(1),(4)$ and (9) (1985).

${ }^{89}$ Id at 1166, citing 29 CFR $\S 5.12(b)(1)$ (1985).

90 Id at 1169.
} 
sent a congruence of interests, and the two agencies would not be in privity.

\section{B. The Specific Overlap Approach and Policy}

As the hypotheticals based on Sunshine and Mervin demonstrate, the specific overlap approach sometimes yields the same result as the traditional Sunshine rule. Like the Sunshine approach, the specific overlap approach can determine privity whether the agencies are plaintiffs or defendants. The two approaches differ in that the specific overlap approach limits privity where the agencies lack congruent interests in and responsibilities over a specific factual situation. The specific overlap approach imputes notice of a prior agency action only when the second agency can expect the first agency to be dealing directly with the same factual situations, thereby undercutting the broad sweep of the traditional Sunshine approach.

The specific overlap approach accommodates the basic policies underlying agency claim preclusion while avoiding the problems inherent in other approaches to privity. First, although it is not as restrictive as the Sunshine rule, the specific overlap approach will significantly limit duplicative agency litigation over single transactions. In addition, the specific overlap approach will limit such litigation more than the common authority approach, since its preclusive force rests directly on the scope of an agency's sphere of activity rather than relying on the existence of a common superior.

Third, unlike the Sunshine rule or the extended primary jurisdiction approach, the specific overlap approach grounds interagency privity in recognizable relationships and provides a reasonable means for agencies to obtain notice of potential preclusion. After an initial reading of statutes and regulations for possible congruence of authority over specific factual situations (plus reading of new statutes and regulations), agencies need only monitor those agencies whose jurisdiction or sphere of litigation activity overlaps their own in specific factual situations. Since agencies deal with statutes and regulations intimately and can be presumed to know the law, the costs of monitoring are lower under this approach than under the Sunshine or primary jurisdiction approaches.

The remaining monitoring costs are simply the by-product of an administrative structure characterized by agency autonomy. Given this autonomy, some monitoring costs are unavoidable. ${ }^{91}$

${ }^{91}$ Although a central body providing information on concurrent activities of other 
Agencies can reduce monitoring costs by developing informal coordination procedures. ${ }^{92}$ Moreover, since notice hinges on the promulgation of a statute or regulation giving an agency authority to litigate over a specific factual situation, notice will occur well in advance of actual preclusion. Because an agency has advance notice that it is in privity with certain other agencies, it can take steps to reduce the costs of preserving its claims before another agency litigates the same transaction.

Most importantly, the specific overlap approach minimizes interference with agency policy objectives. Absent litigation by another authorized agency, an agency is free to plan and schedule its litigation in whatever way it sees fit. Unlike the extended primary jurisdiction approach, the specific overlap approach will not block agency action through a pre-administrative judicial determination of jurisdiction, and agencies can act regardless of whether a court believes that another agency has greater expertise. Of course, once an agency acts, others with overlapping jurisdiction must join in or be precluded, but since agencies know of potential preclusion well in advance through statutes and regulations, they have ample time to coordinate their policy with that of the active agency. The suggested approach respects Congress's delegation of litigation and decision making authority to agencies.

Finally, implementation of the suggested approach may yield two other results. First, as courts and administrative tribunals display an increased interest in statutes and regulations, legislators and rulemakers may pay more attention to the way they distribute litigation power among agencies. Given a concrete definition of privity, legislators and rulemakers can delegate authority in such a way that the procedural constraints of claim preclusion can advance administrative policy. Second, courts will apply claim pre-

agencies might be a simple answer to the problem of monitoring costs, the specific overlap approach is intended to be effective without major structural changes in the administrative state. Such a coordinating body might resolve problems of privity and notice, but only at the expense of creating such a body and foregoing some degree of agency autonomy. Moreover, such a body might prove ineffective. See notes 25,28 , and 31 concerning the failure of the Department of Justice and the OMB to coordinate agency litigation. A less costly and intrusive solution would be to allow agencies to develop procedures for following one another's litigation, such as appointing liaison officers to coordinate litigation with other privy agencies. The specific overlap approach fosters such informal coordination. See note 92.

92 Since 1948, the Justice Department and the FTC have formally and informally coordinated their overlapping litigation of antitrust suits. David L. Roll, Dual Enforcement of the Antitrust Laws by the Department of Justice and the FTC: The Liaison Procedure, 31 Bus Law 2075, 2077-80 (1976). Each agency appoints a liaison officer to exchange information concerning litigation and investigations of antitrust violations, and the agencies have agreed to divide investigatory activity by industry. 
clusion more consistently in administrative proceedings. Since the proposed standard is more flexible than the Sunshine approach and accommodates the special considerations of governmental litigants, courts can apply claim preclusion in the administrative context without resort to the arbitrary limits and restrictions previously needed to ensure just results. 